\title{
Adapting Board Games to Stimulate Motivation in Vocabulary Learning in Six Year Old Learners A Case Study
}

\author{
Gerovasiliou Fotini \\ School of Humanities, Hellenic Open University, Greece \\ E-mail: fofi_dina@yahoo.gr
}

Dr. Zafiri Makrina

School of Humanities, Hellenic Open University, Greece

ESP/ EAP Language Teacher, Aristotle University of Thessaloniki

Teacher Trainer, ASPAITE, Thessaloniki

E-mail: m_nzafiri@yahoo.gr

Received: May 23, 2017 Accepted: June 13, 2017 Published: August 1, 2017

doi:10.5296/jse.v7i3.11323 URL: https://doi.org/10.5296/jse.v7i3.11323

\begin{abstract}
The particular study focuses on the use of board games and argues that they are a useful and practical tool in order to stimulate six year old students' motivation in learning topic vocabulary in a foreign language classroom. It explains how a number of ready-made board games can be adapted, according to the educational aims, the students' age and language level in order to maximize positive results in foreign language learning. Through playing board games, young students not only become much more active, but they also anticipate coming to the learning classroom more eagerly since they involve the elements of joy, interaction, cooperation and competition. Moreover, games place the teacher in a background role, acting more as a facilitator; therefore they allow students to take on more responsibility for their learning.

To this end, an experimental study design, employing both qualitative and quantitative data research tools, was adopted. The participants, who were eight students of six year old age, were divided into two groups. In the experimental group, only board games were applied in order to give students the opportunity to practise the disseminated topic vocabulary while the
\end{abstract}




\section{Macrothink}

control group practised their vocabulary through the activities proposed by the coursebook and the worksheets which were constructed by the researchers. A pre-test and post-tests were administered to students before and after the action research and semi-structured interviews with the students of the experimental group were conducted in order to probe into the students' views concerning the proposed tool and method of instruction. The analysis of the tests indicated a difference in favor of the experimental group. Finally, the findings of the students' responses revealed the beneficial effects of using board games to stimulate vocabulary learning to students of the specific age group and language level.

Keywords: young learners; vocabulary; board games. 


\section{Introduction}

Teaching and learning a foreign language is a demanding process especially for young learners who, very often become bored, listless and uninterested when they feel that a task is difficult. Being that the case, the teacher should create a learner-centred and motivating environment so as to achieve maximum results in language learning. In this respect, games are considered an interesting and challenging activity to be employed in the foreign language classroom. However, it is not always easy to find a game that would fit into the language syllabus therefore, a good alternative for the teacher would be to create or adapt a board game.

\subsection{Young learners}

Halliwell (1992, pp.3-8) brings forth six characteristics of young language learners presented as follows:

- Young learners are able to understand a message without comprehending every single word. This is further enhanced through facial expressions, gestures, demonstrations and visual aids.

- They are creative users and good imitators of the target language in the sense that they do not feel afraid or embarrassed to take part in activities which require using the target language to communicate and convey their message even though they have a limited knowledge in the foreign language.

- They have the ability to learn the language indirectly, by taking in information from the environment that surrounds them instead of focusing on a single task they are being taught.

- They have a deep sense of fun and play; therefore the teacher should integrate games in the language classroom which accommodates this need.

- Taking into consideration that young learners have a vivid imagination, the teacher should create an environment that encourages the combination of their creative imagination with real language use.

- They are social and they have the need to interact and talk with both their peers and with their teacher. The teacher should thus encourage students to become engaged in various types of interaction because communicating in different contexts resembles real life situations.

Another typical characteristic of young learners is the fact that they are easily distracted and they have limited attention span; therefore teachers should engage them in challenging and creative activities that arouse their curiosity and interest towards language learning (Slattery $\&$ Willis, 2001). Piaget (1967) concluded that children are active learners and thinkers and they are able to construct knowledge by interacting with their environment in four developmental stages. He stated that children start at the sensori-motor stage, where they exhibit a limited use of symbols and language and then they proceed through the pre-operational stage, where they like being engaged in symbolic play and they also tend to 
be egocentric. As they move to the concrete operational stage, they start thinking logically by relating new concepts to concrete objects before they finally reach the formal operational stage, where they display intelligence through a logical use of symbols and understanding of abstract concepts (Shin \& Crandall, 2014).

Philip, Oliver and Mackey (2008) state that students who are six years of age enjoy participating in language play activities where they are given the chance to practise, repeat and internalize the new language form which leads to their development. Rivers (1968, as cited in Broughton, Brumfit, Flavell, Hill, \& Pincas, 2003) indicates that "repetition gives young learners a sense of achievement and assurance" (p.169). Moreover, according to Vygotsky (1962, as cited in Bouniol, 2004), young children are able to construct knowledge through social interaction with other people. It is hence the teacher's responsibility to work actively within their Zone of Proximal Development (ZPD) by engaging them, on the one hand, in activities that encourage interaction both with the teacher and their peers and, on the other hand, in activities that appeal to their senses and involve movement in order to help them make learning meaningful (Scott \& Ytreberg, 1991). The Zone of Proximal Development (ZPD) is used to refer to the difference between a child's ability to achieve things on its own and the child's ability to achieve things with assistance (Lightbown \& Spada, 2000). However, because they are young, they need more support and scaffolding by the teacher (Cameron, 2001). Scaffolding is further enhanced through the use of different stimuli such as visuals, realia and games and by adjustment of the language to the students' level in order to make the input more comprehensible (Shin \& Crandall, 2014).

All of these characteristics create a dynamic and challenging environment that the teacher should cater for in order to keep the learners engaged during the teaching process. Being that the case, the aim of the particular research is to investigate the effectiveness of using board games in young learners' vocabulary development. Since students cannot learn vocabulary items as separate entities, board games will enable them to participate in a stimulating and active context where they will enjoy using the target language in a communicative manner (Halliwell, 1992).

\subsection{The importance of vocabulary learning}

According to Oxford and Crookal (1990), vocabulary instruction should be of top priority in a teacher's agenda. When learning a foreign language, vocabulary plays a crucial role especially for very young learners who are just beginning to learn English. Research suggests that vocabulary knowledge contributes to young learners' reading comprehension and the overall development of language competence (Stanovich, 2000). Thus, vocabulary teaching especially in the initial stages of learning plays a crucial role in foreign language learning (Schmitt, 2010). According to Gower, Philips and Walters (2005), vocabulary is even more important than grammar because, especially in the early stages, students learn the basic words they need in order to communicate. In order to highlight the importance of vocabulary, Krashen (1987, as cited in Lewis, 1993) stated that "when students travel, they don't carry grammar books, they carry dictionaries" (p.iii). Wilkins (1972, as cited in Thornbury, 2002) reports that "you can say very little with grammar, but you can say almost everything with 
words" (p.13). Through learning words, students start to develop knowledge in the target language. As Laufer (1997) pinpoints, learners have to acquire a fairly large number of vocabulary items in order to attain what he refers to as "the Threshold level for reading comprehension" (p.31). Similarly, as Rubin and Thomson (1994) exemplify, acquiring a large amount of words in the foreign language helps learners not only to understand what they read or hear but also to express themselves fluently and accurately. In addition, according to Bromley (2007), a considerable amount of word knowledge helps students not only to become more confident in using the target language but also to communicate in a more effective and precise manner since words act as a tool for "analyzing, inferring, evaluating and reasoning" (p.528).

Uberman (1998) claims that vocabulary learning is a tedious and strenuous task especially if it is delivered through rote and mechanical strategies. Nevertheless, the ability to retain new words is perhaps the most challenging part in language learning (Holden, 1991). Using games can develop domains of words and relatedness since they enable students to practise and rehearse these words (Graves, August \& Mancilla-Martinez, 2013). Thus, creating a classroom environment where students are encouraged to learn through playing with words can foster motivation in vocabulary learning and development (Thornbury, 2002).

\subsection{Definition and benefits of using games in the EFL classroom}

According to Hadfield (1999), a game is regarded as an activity which involves rules, a goal and an element of fun. In the same vein, Richards, Platte and Platte (1992) define game as an organized activity which involves an objective to be accomplished, a set of rules, competition among the participants and interaction between the players through spoken or written language.

Research proved the pedagogical value of implementing games in language learning. Because of the age and the characteristics of young learners, it is believed that games are a useful tool to motivate them to actively participate in the learning process. Dating back from the nineteenth century, numerous experts in foreign language learning supported the view that play is the work of children (Riley, 2003). Bruner (1983) claimed that learners learn more effectively if they are engaged in hands-on activities. Dewey (1990) believed that children's education depends on action, therefore they learn better while they are playing and being engaged in practical activities which give them the chance to demonstrate and articulate their thoughts. Piaget (1967, as cited in Bouniol, 2004) stated that children are active learners and that they construct knowledge through opportunities offered for action. Finally, Vygotsky (1978, as cited in Bouniol, 2004) claimed that children's development in language learning is better achieved through social interaction with their environment. That being the case, games, provide opportunities for very young learners to use the target language for communication with their peers (Fredericksen, 1999).

Similarly, in recent literature, Uberman (1998) points out that learners learn and develop better when they are at play. Hadfield (1999) clearly states that games should be integrated in the language syllabus not only because they are amusing activities, which promote real communication and use of the target language, but also because they "constitute a bridge 
between the classroom and the real world" (p.8). As young learners are eager to learn, the teacher's responsibility is to provide a positive and stimulating environment which focuses on building confidence and developing their learning.

When students enter the classroom, feelings of anxiety and insecurity arise because of the fact that they confront unknown language structures (Mubaslat, 2012). That is especially true in classrooms which consist of early beginners, as is the case in the particular context, where they are expected to learn their first foreign language at the same time that they are learning their first language (Pàlànova, 2010). In this regard, the use of games is considered a stimulating activity which should be applied in the foreign language classroom. Game-based tasks establish a non-stressful and enjoyable environment which will help students learn more vocabulary and retain new items longer (Mehregan, 2014). Moreover, games provide a way to ensure that all learners are included in the learning procedure since they reduce the tension and anxiety which is triggered during the learning effort (Dalton, 2006). As Pàlànova (2010) reports, through games children are encouraged to learn not to hate the foreign language and promote positive feelings towards it; as a consequence it becomes easier to cultivate and strengthen this relationship and help students develop more.

Implementing games in the language classroom promotes learners' motivation, while at the same time it activates their participation and concentration (Kirikkaya, Iseri \& Vurkaya, 2010). Besides these elements, games prompt learners to use the target language in a more creative and communicative fashion (Cunningham, 2009). In addition, according to Papastergiou (2009), through games students learn more actively and with greater interest which enhances a deeper understanding of the learnt content in comparison to a more traditional method of teaching. Through well-organized games, students acquire the target language subconsciously while playing because they commit themselves to the activities they are engaged in (Vernon, 2009). In the same sense, according to Halliwell (1992), "games should not be regarded as a filler for the end of the lesson" (p.6); instead, they should have a central role and act as "real work" since they give students the chance to learn and practise the target language in a subconscious and spontaneous manner because students focus on the task of playing the game and not on the correct use of the language (Halliwell, 1992, p.6).

Games not only encourage and increase cooperation but they also capture the learners' attention and participation (Mubaslat, 2012). Another benefit is that they establish a stimulating competitive atmosphere that promotes the students' interaction, yet in a friendly and fun environment (Ersoz, 2000). Finally, Lee (1995) believes that games are a welcome break from the ordinary routine that exists in the language classroom.

Taking all this into consideration, it can be concluded that creating an environment which gives students the chance to learn by doing and by interacting with each other is very important in a young learners' classroom. Implementing games contributes not only to cooperative learning since students work in groups and share knowledge but also promotes a learner-centred environment which endorses the learners' interests, giving students the opportunity to learn by playing. 


\subsection{Why choose board games}

Papert and Harel (1991) exemplify that learning is better achieved through real life situations and the shaping of concepts through making things. Although digital games have largely been part of the students' everyday life, there are instances where the use of computers in classrooms is limited or even missing, as is the case in the particular teaching context (Razak \& Eswaran, 2013). What is more, digital games do not exhibit any human interaction and they are passive in nature (Kirriemuir \& Mcfarlane, 2004).

On the contrary, board games provide face to face interaction, physical action and verbal tone (Billinghurst \& Kato, 2002). Board games are considered active and help students to be emotionally involved by establishing emotions of happiness, anticipation and excitement, all of which foster a positive effect in language learning (Langran \& Purcell, 1994). In addition, the organization and implementation of board games is more feasible in a language classroom, especially in those which lack in digital media, because they function as a handy and convenient tool usually consisting of a track, pawns, dices and cards (Wu, Chen \& Huang, 2014). Therefore, it is likely to be more easily accessed without the fear of crashing, as it is occasionally the case with the computer's operation system.

Gardner (1993) in his theory of Multiple Intelligences admits that students should be facilitated to resort to their preferable intelligence while learning (Bouniol, 2004). Board games combine various intelligences, namely visual/ spatial intelligence since students can visualize pictures which are presented on the track itself, interpersonal intelligence as students interact with their peers and body-kinesthetic intelligence because games provide hands on learning by touching real objects like the track, the dice and the cards (Lane, 2006).

What is more, language games including board games are interactive in the sense that players interact with each other throughout the game in line with its rules and with the context presented during the game (Kapp, Blair \& Mesch, 2014). As Kirriemuir and Mcfarlane (2004) report, when children experience learning through games, it seems to affect their expectations because they tend to prefer activities which are fast, active and exploratory. Moreover, they also establish an environment for meaningful repetition (Lewis \& Bedson, 1999). According to Treher (2011), a well-designed game provides significant repeat play value giving the incentive to students to play the game again and again until they finally feel confident about giving the right answer. Therefore, it is more likely that the words will be better practised and related to their interests and even more easily accessed in memory (Aslanabadi \& Rasouli, 2013).

Board games are considered a useful tool because they create an engaging and playful atmosphere where students are neither inhibited by making mistakes nor excluded if they do not know an answer, thus fostering their self-confidence (Treher, 2011). What is more, it ensures that reluctant or shy students will definitely participate by using the target language (Lewis \& Bedson, 1999). Even the board track itself enables students to create visual images in their mind, recall and eventually be able to connect and apply the information they have learnt during the lesson (Treher, 2011). Using board games can develop domains of words and relatedness, since they enable students to practice and rehearse these words, as mentioned 
above (Graves et al., 2013). As Bromley (2007) points out, when vocabulary is presented in a game-like context students can "explore pronunciations, visual display and meanings simultaneously" (p.528). The ease of devising ready-made board games helps teachers to adjust anything they want to teach, which in this particular case is vocabulary, in a playful context which enables students to practise and consolidate the new words better. This aspect of board games adds to their practicality for classroom implementation (Hinebaugh, 2009). Last but not least, board games foster the development of social skills such as communicating, taking turns, sharing, waiting, risk-taking and enjoying interaction with peers (Couzin, 2002).

Finally, according to Ersoz (2000), language games, including board games, help students to become involved in cooperative and team learning which establishes an essential social relationship among the participants in the sense that they are encouraged to help each other since learning takes place in a game like context rather than a race. Therefore, it can be concluded that board games create an enjoyable learning environment in which students look forward to participating.

\section{The purpose of the study}

Based upon the literature concerning games, the aim of the particular research is to investigate and present the effectiveness of board games in order to motivate very young language learners in learning basic English vocabulary based on the principles of the Common European Framework. More specifically, the particular study addresses the following research questions:

1) How can board games motivate six year old students to learn vocabulary?

2) In what way do board games have a positive effect on students' vocabulary knowledge?

3) Can board games help young learners of the specific age group to remember the target vocabulary words better in comparison with the traditional book-based method?

The researchers anticipate that the proposed board games will help students of the specific age group and language level to retain and remember the target vocabulary better, as opposed to those students who follow the conventional book-based method. The researchers also hope that the proposed study, which involves a number of well-known board games, will pave the way for encouraging teachers to adapt and implement board games not only in the private sector, which opts for smaller groups of students as is the case in the particular research, but in the public sector as well, which addresses larger groups of students.

\section{Methodology}

The researchers believe that the most suitable methodology for conducting a study concerning the effectiveness of board games on beginners' motivation and vocabulary development is to implement a mixed method research, involving both qualitative and quantitative data collection techniques, since they tend to inform and support each other (Creswell, 2014). 
Being that the case, qualitative data could derive from recorded interviews, observations during the actual teaching of the lessons, field notes and photos, as is the case with the particular teaching context, all of which aim at achieving a richer description of the process (Dörnyei, 2007).

On the other hand, carrying out quantitative methodology involves gathering numeric data while studying a sample of the population (Creswell, 2014). According to Mills, Eurepos \& Wiebe (2010) "quantitative analysis can be used to complement qualitative analysis" (p.760), as it was the case in the particular research. In this specific occasion, despite being a small-scale research, quantitative data were collected by using pre and post tests, the results of which were compared and analyzed in order to measure the effect of the proposed intervention, as opposed to the impact of the traditional book-based instruction.

All things considered, Dörnyei (2007) exemplifies that a mixed method research "offers a potentially more comprehensive means of legitimizing findings" (p.62) and therefore, it contributes to the credibility of the research since triangulation is achieved through the inclusion of both qualitative and quantitative sources.

\subsection{Action research approach}

Since the researchers act as investigators of their own context, the mode of investigation employed in this particular study is based on action research. According to Burns (2010), action research is related to the ideas of "reflected practice and the teacher as researcher" (p.2). More particularly, she states that in action research, the teacher explores his/her personal context more systematically in order to improve his/her teaching practice. Kuhne and Quigley (1997) discuss that action research is a systematic process which involves analysis, observation and data collection in a natural teaching context with a view to finding possible answers concerning a problematic area that may impede the teacher's practice. In the same vein, as Wallace (1991) contends, action research is a rigorous, reflective practice initiated by the teacher referring to practical problems occurring in his/her own teaching context which should have immediate and practical outcomes, without necessarily having a general application. Last but not least, action research requires teachers to examine a school-based topic in order to increase knowledge or improve their teaching practice (Gay, Mills \& Airasian, 2003). The results of this reflection and improvement lead both to the teacher's growth and the students' learning (Burns, 2010).

Kemmis and McTaggart's (1988, as cited in Burns, 2010) propose that action research should include four broad phases namely, "planning, action, observation and reflection" (pp.7-8). Considering this model, as far as the stage of planning is concerned, the researchers have conducted action research, as they needed to develop a deeper understanding concerning the effectiveness of board games on a sample population of six year old students as regards vocabulary learning. Moving towards the phase of action, the researchers wanted to investigate whether the proposed intervention has an impact on the particular learners. In order to achieve this, the researchers planned a number of lessons, adapting a number of board games which were taught and recorded (i.e. stage of observation), in order to gain knowledge of what was 
happening in the classroom and be able to reflect and offer answers to the research questions which will be presented further on in this paper (i.e. reflection stage).

\subsection{Case study}

The particular research is also characterized as a case study, which is a subordinate to action research, since it focuses on a single instance (Gerring, 2004). Thus, talking about this specific occasion, the participants form two classes of early beginners in two private language centers in two rural areas in northern Greece. A total of eight participants, who enrolled in both language centres, were six year old students attending the first grade in primary school. They were all monolingual, native speakers of Greek without any prior knowledge of the English language. Therefore, according to the Common European Framework of Reference (2001), they were beginners belonging to the pre-A1 language level. Apart from participating in a forty-five minute session, which was held once a week for an eleven week period for the sake of the particular study, they were also attending one hour instruction of teaching English as a foreign language at their schools, as part of the curriculum implemented in the Greek public sector.

Richards (2003) believes that a case study, which is considered a small-scale individual research, should be "every bit as respectable as large funded projects and therefore all levels of research must be treated equally seriously" (p.xx). In addition, according to Wallace (1991), although a case study research requires a great amount of work and time, it is highly appreciated since "it brings together a whole range of theoretical issues and applies them to a real life context" (p.40). After all, as Siggelkow (2007) annotates, a case study can be an effective approach since it provides useful and enlightening insights to the researcher through exposure to a particular policy which has been implemented.

\subsection{Experimental design}

As part of the action research procedure, this study also adopts an experimental research design involving differentiated teaching for a period of eleven weeks. According to Phakiti (2014), an experimental design involves two equivalent groups which are being exposed to two different conditions. Although both groups had the same characteristics in terms of age and language level, yet, this case is considered quasi-experimental, which according to Dörnyei (2007) is similar to an experimental design, since the groups were not assigned randomly due to practical constraints which had to do with the owner's reservations as regards the parents' attitude towards the differentiated instruction which would be followed by the researchers (Creswell, 2014). Thus, in the particular context, one group, which was designated as the control group, was taught through a conventional coursebook following the syllabus that was in line with the specific age group and language level while the second group, which served as the experimental group, was given the chance to practise new vocabulary through board games.

\subsection{Description of the book-based context and the experimental procedure}

Before presenting both the traditional and the experimental procedure, it is worth mentioning that the study took over a period of eleven weeks to be completed. It consisted of twenty two lessons which lasted for forty five minutes each. The control group was only engaged in a 
traditional, book-based methodology; nonetheless apart from the coursebook's and workbook's activities, for the sake of practising the target vocabulary in a more interesting fashion, the researchers also incorporated craft activities, colouring activities, as well as songs.

Unlike the control group, in the experimental group, only board games were used during the practice stage. However, prior to employing board games in the class, the specific students participated in a lesson which engaged them in learning words around the topic of parts of the body involving four modes of teaching, namely songs, puppets, storytelling and finally board games. These particular methods of teaching were chosen since they were considered appropriate for students of the particular age group and language level and they were also in line with the curriculum (Curriculum Development Council, 2002).

After the end of the lesson, the researchers carried out a focus group semi-structured interview in order to find out the students' preferable method of teaching. According to Dörnyei (2007), this type of interview is a convenient way to gather data by giving the participants the chance to share their views and even spark ideas from the other participants. Because of the fact that the interviewees were very young, during the interview the researchers acted as facilitators in order to make sure that even the shyer students would have the chance to contribute to the conversation (Dörnyei, 2007). The particular type of interview would also pave the way for the final one-to-one semi-structured interview. The researchers transcribed the interview in order to acquire descriptive data through the students' responses and it was concluded that the students would prefer to participate in the lessons that would integrate board games because they thought that they were more enjoyable. As far as the other modes of teaching were concerned, the students mentioned that if it had not been for the researchers' help and the proposed activity, they would not have understood the story, although it was a very familiar one. As regards the songs, the students claimed that they were able to follow the songs because the researchers had replaced the target words with pictures in order to help them understand. Finally, in the case of the puppets, the students said that they were able to use the target words more in the class; however, they were not of their preference.

Taking everything into consideration, fifteen different board games were employed and adapted around the topic vocabulary entailed by the disseminated syllabus in order to promote students' maximum potential to practice the target vocabulary in a fun and engaging manner. The board games consisted of tracks, pawns, dices, cards and other appealing material in order to stimulate the students' motivation and interest (Huang \& Levinson, 2012). All of the board games resembled a simple and repetitive character (Lewis \& Bedson, 1999).

In particular, the first lesson explored the topics of food and drink. A total of nine words were practiced through the use of the so-called board game "Chutes and ladders". The procedure entailed that each student in turn would roll the dice, move his/her pawn on the board and name the food or the drink item that was shown. Besides the chutes and ladders that were depicted on the board, the researchers also added some instructions which made the students 
miss a turn, to move ahead or go back to the start of the track in order to make the game more intriguing.

The second lesson was constructed around the topic of colours. Seven core colours were practiced by playing a board game which was called "Jacks monkey tree game". For the sake of the particular game, the researchers also implemented an eight-sided dice in order to encompass all the colour items. The game involved students in rolling the coloured dice, removing a stick with the correspondent colour from the tree and naming which colour it was.

The third lesson focused on the topic of school items. Six words were practiced with the use of a board game which was called "Don't wake Daddy". Students took turns rolling the dice, moving their pawns and naming the school item that was shown on the track. However, if they landed on a space with a picture and number and they did not have the card that matched the space, they had to push the button on the alarm clock as many times as was indicated on that space. If they woke daddy, he would pop up in bed.

The fourth lesson had to do with the members of the family. The researchers assumed that the students would remember those words easier since they were almost similar to their Greek equivalents; that was why two board games were employed in order to give students the chance to practise the particular words. The first one was a typical board game consisting of track, pawns and a dice and the second one was "bingo" where all the images should be marked in order for one of the students to be the winners.

The fifth lesson dealt with the topic of means of transport. Ten words were practiced through a board game called "wheels, rails and propellers" according to its Greek translation. Students had to claim routes and create a continuous path with their cards, naming the vehicle that was depicted on their card each time.

In the sixth lesson, the researchers used the well-known "UNO" board game in order to help students identify, recognise and practise the numbers from one to ten and also recycle colours. Moreover, while playing the game, students learnt to take turns and engage in friendly competition.

The seventh lesson involved two board games in order to allow students to practise the words around the topic of the parts of the body. The first was a typical board game involving a track, pawns and a dice and the second one was the board game called "operation" where students had to remove the part which was in pain while listening to a funny noise.

Lesson eight was about animals. Students were given the chance to practise those words through a typical board game consisting of a track, pawns and a dice and another one where they had to collect as many cards as they could, while listening to the researcher who called out the names of the animals, by using a sticky hammer.

Lesson nine focused on the topic of action verbs. Six words were practised through the use of a typical board game including a track, pawns and a dice and a domino game where students took turns placing picture dominoes on the board that matched one side of what was already there. 
Finally, the last two lessons dealt with the alphabet. Apart from practising the letters, these games engaged students in a friendly competition since the one who reached the end of the track first was the winner.

Having presented both procedures, the next step is to describe the instruments that were used to collect the data.

\subsection{The use of qualitative and quantitative tools for data collection}

According to Gay et al. (2003), qualitative data resources involve collecting descriptive and narrative data which will give the researcher a deeper understanding of the phenomenon under discussion. Talking about the particular context, the researchers have collected data through recordings, journals and semi-structured interviews.

As far as the quantitative tools are concerned, according to Dörnyei (2007), a test is one of the most common tools in order to gather quantitative data. In this particular case, pre- and post- tests were administered to students in order to measure the effectiveness of the proposed intervention. Talking about the particular teaching context, practical considerations had been taken into account before choosing the format of the specific tests. As Black (2004) points out pre- and post- tests should contain items which are appropriate for the students' age and language level. The particular students were early beginners with no prior knowledge in English and unable to produce any written text in the English language, therefore the researchers adapted the format of the Peabody Picture Vocabulary Test, which is abbreviated to PPVT. Although a recent study defined the particular kind of test as a diagnostic tool for identifying language impairment, it can be also used in order to assess children's and adults' receptive and productive vocabulary knowledge (Hoffman, Templin \& Rice, 2012).

The adapted version of both the pre- and post- tests for the particular study consisted of multiple choice questions in which three pictures were shown for each vocabulary word (Hoffman et al., 2012). During the implementation of the pre- and post- tests, the researchers called out a vocabulary item while the students had to circle the correct picture which showed the word they heard.

\section{Presentation and analysis of the results}

In this chapter, the researchers attempted to present and analyze whether the students of the experimental group have benefited from the proposed intervention in comparison to the students of the control group, who attended lessons following instruction only through the disseminated coursebook. To this end, the statistical software Minitab17 has been used in order to analyze the quantitative data through paired T-tests. Moreover, the qualitative data collected through the students' responses during the conduct of the semi-structured interviews were described in a narrative fashion in order to portray their views.

Before the analysis of the results, it is worth mentioning that according to de Winter (2013), "it is feasible to conduct a paired T-test when sample sizes are small as long as the true effect size is expected to be large" (p.7). A paired T-test is used in order to compare and describe whether the means of two independent groups significantly differ (Minitab, 2017). This can 


\section{I Macrothink}

be concluded if the level of significance of the $p$-value is less than $0.05(p<0.05)$ (Minitab, 2017). Throughout the tests, the capital letter $\mathrm{C}$ stands for the nomination of the control group whereas EX stands for the nomination of the experimental group.

\subsection{Analysis of the pre-test}

The pre-test was administered to both groups before the intervention in order to make sure that all the students were at the same language level, thus homogeneous. As it is shown in the following report, the mean score of the experimental group is 2.75 whereas the mean score of the control group is 3 . This denotes that there is no significant difference between the mean scores of the two groups; therefore both groups are equal in terms of their language level competence.

\section{Report 1: Paired T-test for the mean of the experimental and the control group conducted before the intervention}

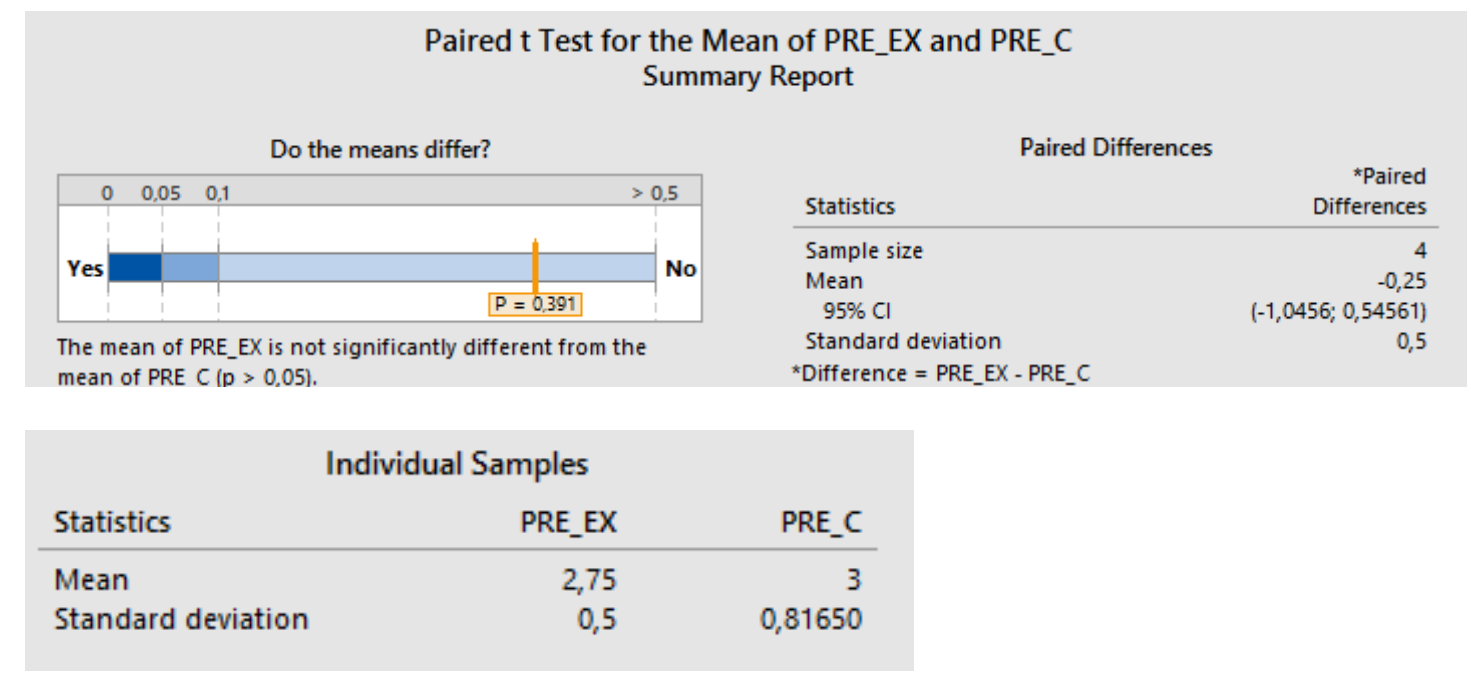

\subsection{Analysis of the post-tests}

The delayed post-tests were run to compare the mean scores of both the experimental and the control group in order to probe into the effect of using board games so as to help six year old students remember the words better as opposed to implementing the book-based instruction and also to determine whether there is a statistical difference between the two groups.

As far as the first post-test is concerned, as it is displayed in the following report, the mean score of the control group is 8.25 while the mean score of the experimental group is 9 . The variation by subtracting the two mean scores is 0.75 and because the result is positive, it indicates that the experimental group did better than the control group. However, the p-value is $0.108(\mathrm{p}>0.05)$ which suggests that although there is a variation between the two mean scores, this difference is not statistically significant but there is a trend for the experimental group. 


\section{Macrothink}

Report 2: Paired T-test for the mean of the experimental and the control group concerning the first lesson (food)

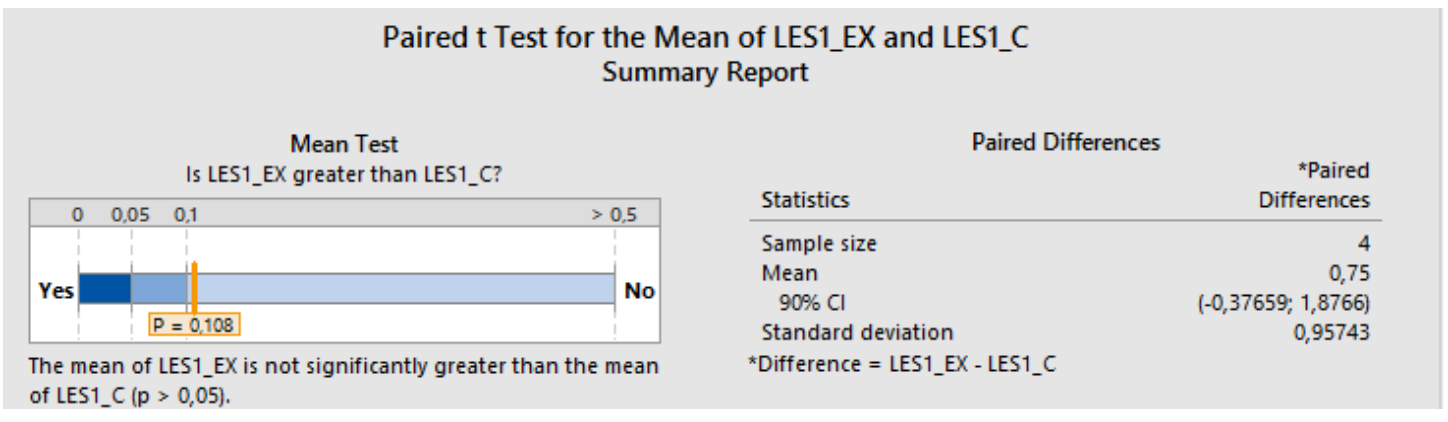

\begin{tabular}{lrr}
\multicolumn{3}{c}{ Individual Samples } \\
Statistics & LES1_EX & LES1_C \\
\hline Mean & 9 & 8,25 \\
Standard deviation & 0 & 0,95743
\end{tabular}

Moving towards the second post-test, the report shows that the mean score for the experimental group is 7 while the mean score for the control group is 6 . The variation by subtracting the two mean scores is 1 and because the result is positive, it indicates that the experimental group performed better than the control group. What is more, the p-value is $0.046(\mathrm{p}<0.05)$, which suggests that there is a variation between the two mean scores, and this difference is also statistically significant.

Report 3: Paired T-test for the mean of the experimental and the control group concerning the second lesson (colours)

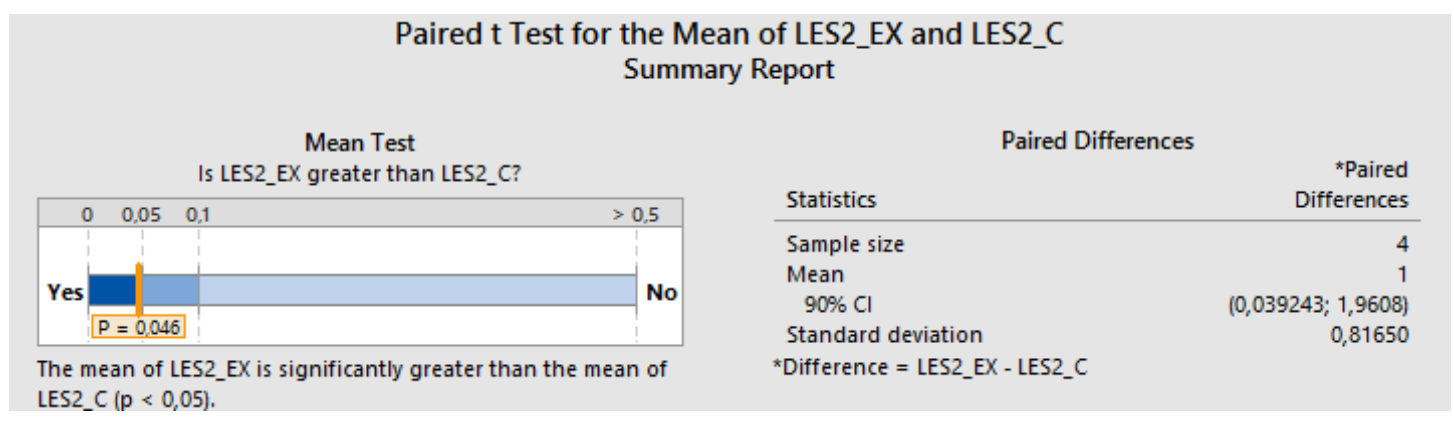

\begin{tabular}{lrr}
\multicolumn{2}{c}{ Individual Samples } \\
Statistics & LES2_EX & LES2_C \\
\hline Mean & 7 & 6 \\
Standard deviation & 0 & 0,81650
\end{tabular}

The following report presents the descriptive data and the T-test for the results obtained from the third post-test. The mean for the experimental group is 5.75 while that of the control group is 5 . This implies that the experimental group performed better than the control group; 


\section{Macrothink}

however because of the fact that the $p$-value is $0.222(p>0.05)$, even though there is a variation between the two mean scores, this difference is not statistically significant.

\section{Report 4: Paired T-test for the mean of the experimental and the control group concerning the third lesson (school items)}

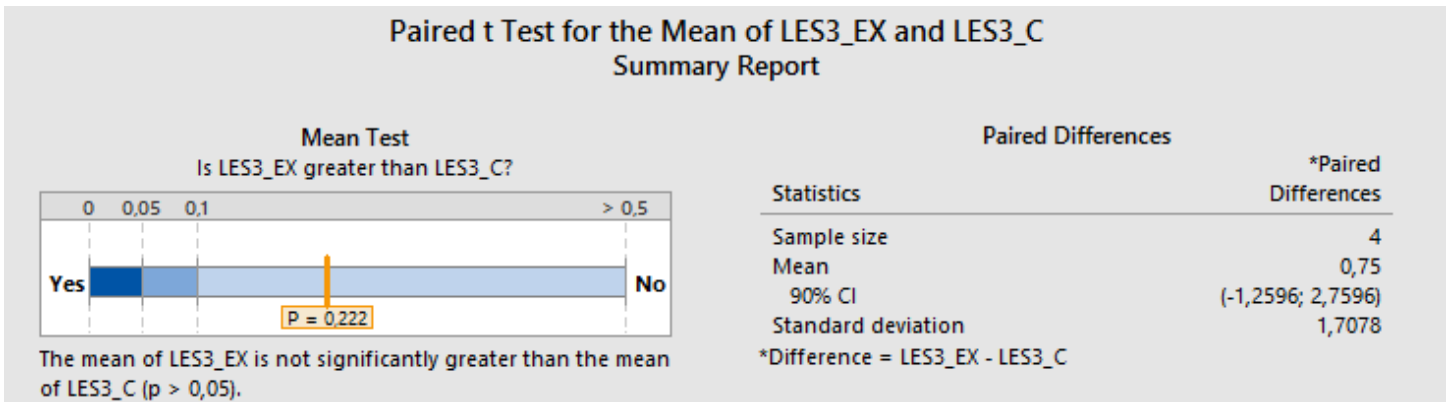

\begin{tabular}{lrr}
\multicolumn{2}{c}{ Individual Samples } \\
Statistics & LES3_EX & LES3_C \\
\hline Mean & 5,75 & 5 \\
Standard deviation & 0,5 & 1,4142
\end{tabular}

As far as the fourth post-test is concerned, because of the fact that the particular lesson referred to the words concerning the members of the family, it was found that both groups had given correct answers to the specific post-test since the words were almost similar to their Greek equivalents. As a result, the particular report cannot be graphically determined.

Nevertheless, from the fifth to the last lesson, the learning achievement between the two groups significantly differs. To be more precise, as regards the fifth lesson, the descriptive data and the T-test for the results obtained from the fifth post-test show that the mean score for the experimental group is 10 while the mean score for the control group is 7.75 . The variation by subtracting the two mean scores is 2.25 and because the result is positive, it indicates that the experimental group performed significantly better than the control group. What is more, the $p$-value is $0.009(p<0.05)$ which suggests that there is a variation between the two mean scores, and this difference is also statistically significant. 


\section{Macrothink}

Report 5: Paired T-test for the mean of the experimental and the control group concerning the fifth lesson (means of transport)

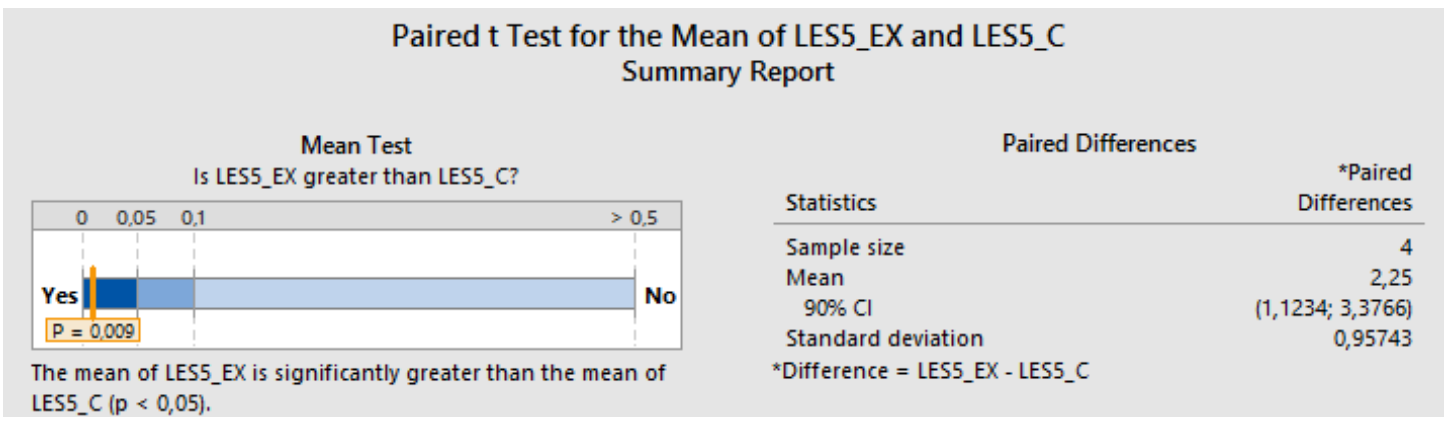

\begin{tabular}{lrr}
\multicolumn{3}{c}{ Individual Samples } \\
Statistics & LES5_EX & LES5_C \\
\hline Mean & 10 & 7,75 \\
Standard deviation & 0 & 0,95743
\end{tabular}

As concerns the sixth post-test, the report shows that the mean score for the experimental group is 14 , while the mean score for the control group is 11.25 . The variation by subtracting the two mean scores is 2.75 and because the result is positive, it indicates that the experimental group performed significantly better than the control group. What is more, the p-value is $0.011(\mathrm{p}<0.05)$ which suggests that there is a variation between the two mean scores, and this difference is also statistically significant. Therefore, it can be assumed that the students of the experimental group showed an improvement which could be attributed to the intervention adopted.

Report 6: Paired T-test for the mean of the experimental and the control group concerning the sixth lesson (numbers and toys)

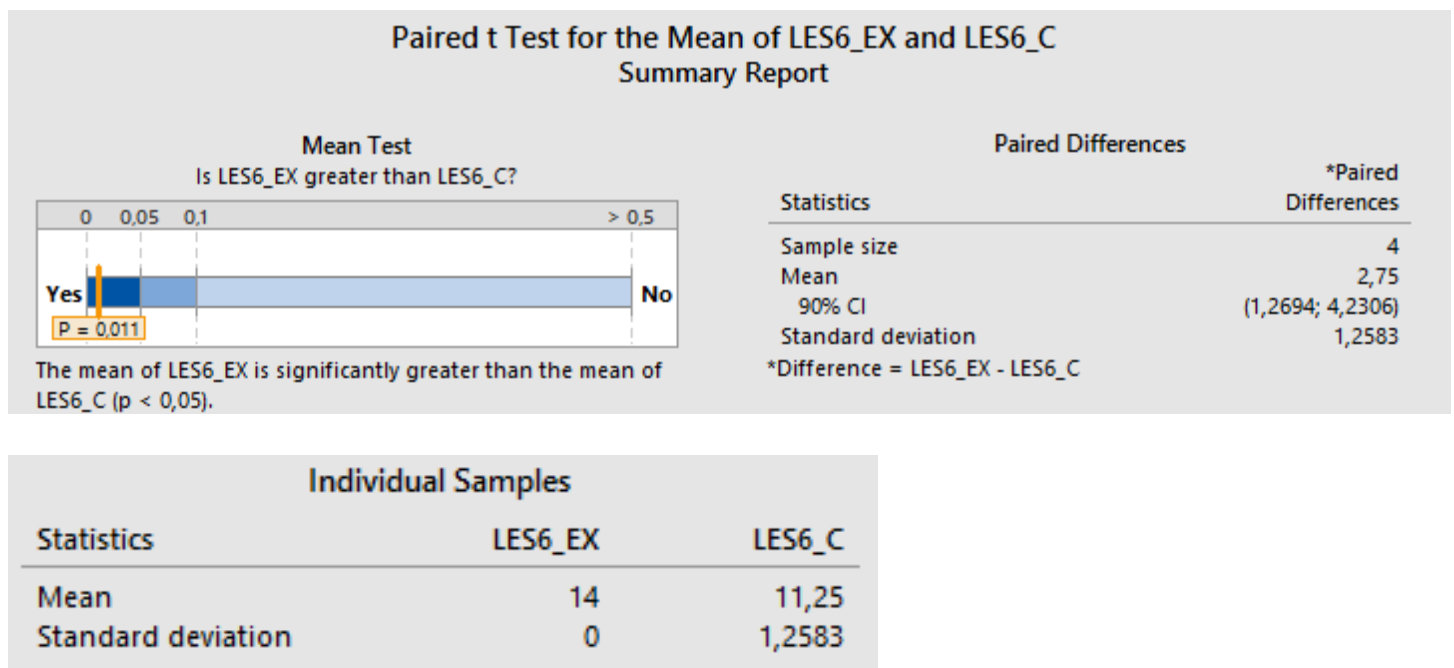

With regard to the seventh post-test, the report shows that the mean score for the experimental group is 8 while the mean score for the control group is 4.5 . The variation by subtracting the two mean scores is 3.5 and because the result is positive, it indicates that the 
experimental group performed significantly better than the control group. What is more, the $\mathrm{p}$-value is $0.030(\mathrm{p}<0.05)$ which suggests that there is a variation between the two mean scores, and this difference is also statistically significant.

Report 7: Paired T-test for the mean of the experimental and the control group concerning the seventh lesson (parts of the body)

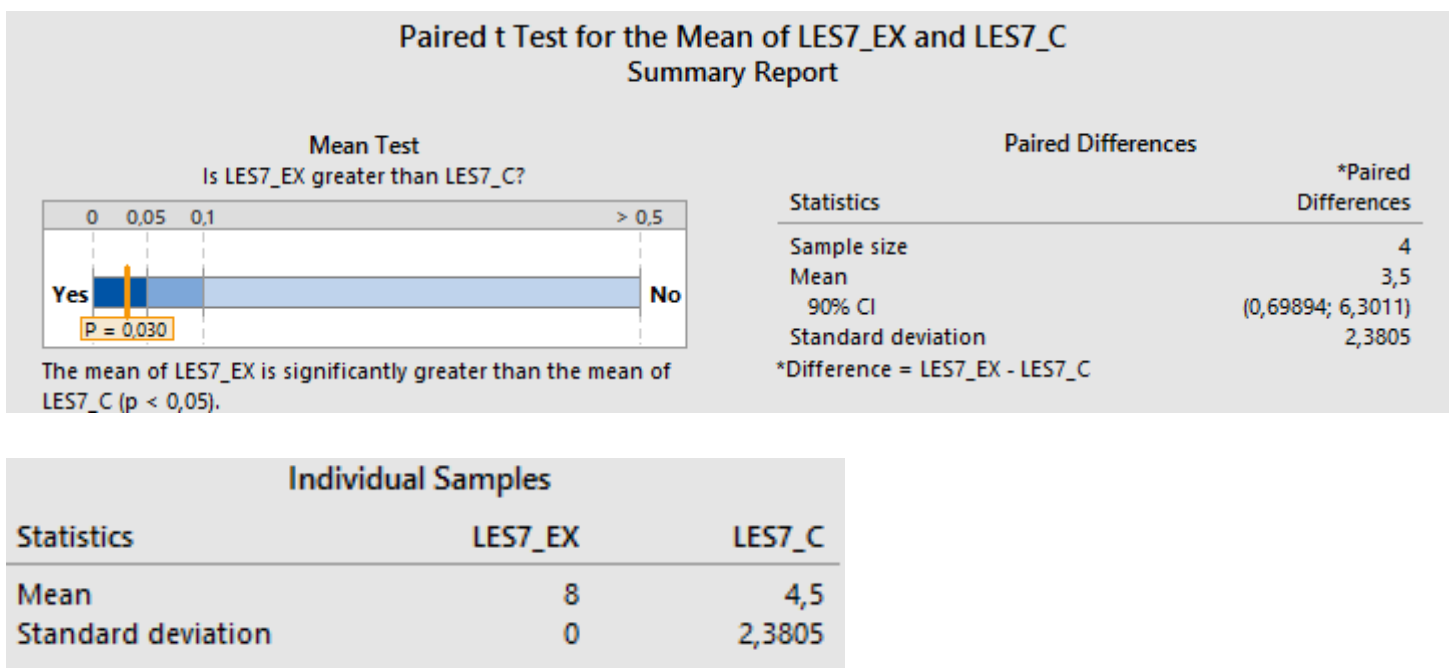

The next report presents the descriptive data and the T-test for the results obtained from the eighth post-test. It is found that the mean score for the experimental group is 13 while the mean score for the control group is 10.25 . The variation by subtracting the two mean scores is 2.75 and because the result is positive, it indicates that the experimental group performed significantly better than the control group. What is more, the $p$-value is $0.005(p<0.05)$ which suggests that there is a variation between the two mean scores, and this difference is also statistically significant.

Report 8: Paired T-test for the mean of the experimental and the control group concerning the eighth lesson (animals)

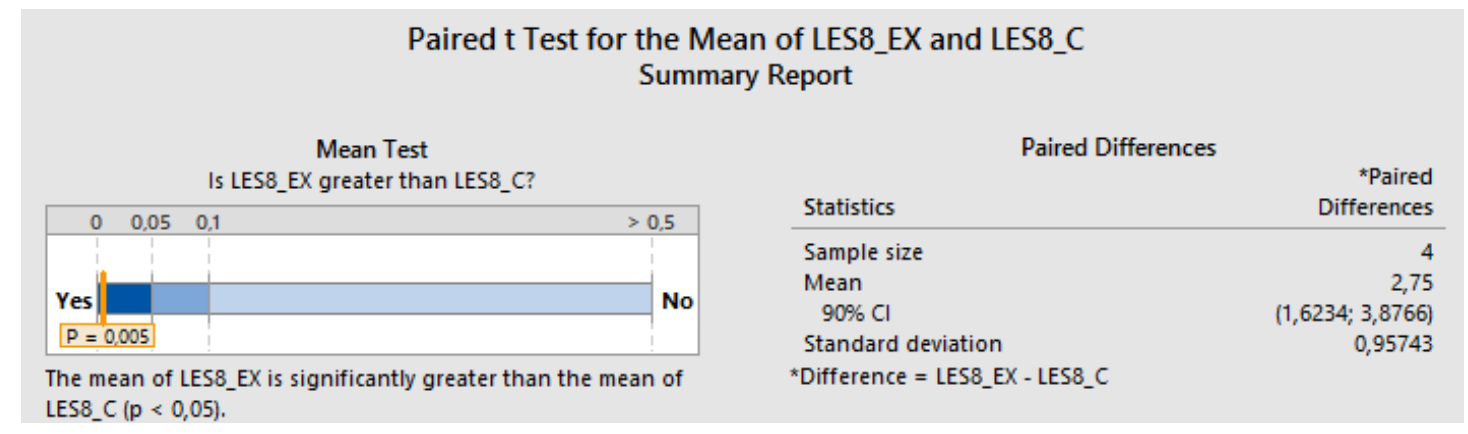

\begin{tabular}{lrr}
\multicolumn{2}{c}{ Individual Samples } \\
Statistics & LES8_EX & LES8_C \\
\hline Mean & 13 & 10,25 \\
Standard deviation & 0 & 0,95743
\end{tabular}




\section{Macrothink}

As far as the ninth lesson is concerned, the T-test analysis yields that the mean for the experimental group is 7 while the mean score for the control group is 3.75 . The variation by subtracting the two mean scores is 3.25 and because the result is positive, it indicates that the experimental group performed significantly better than the control group. What is more, the $\mathrm{p}$-value is $0.003(\mathrm{p}<0.05)$ which suggests that there is a variation between the two mean scores, and this difference is also statistically significant.

\section{Report 9: Paired T-test for the mean of the experimental and the control group concerning the ninth lesson (action verbs)}

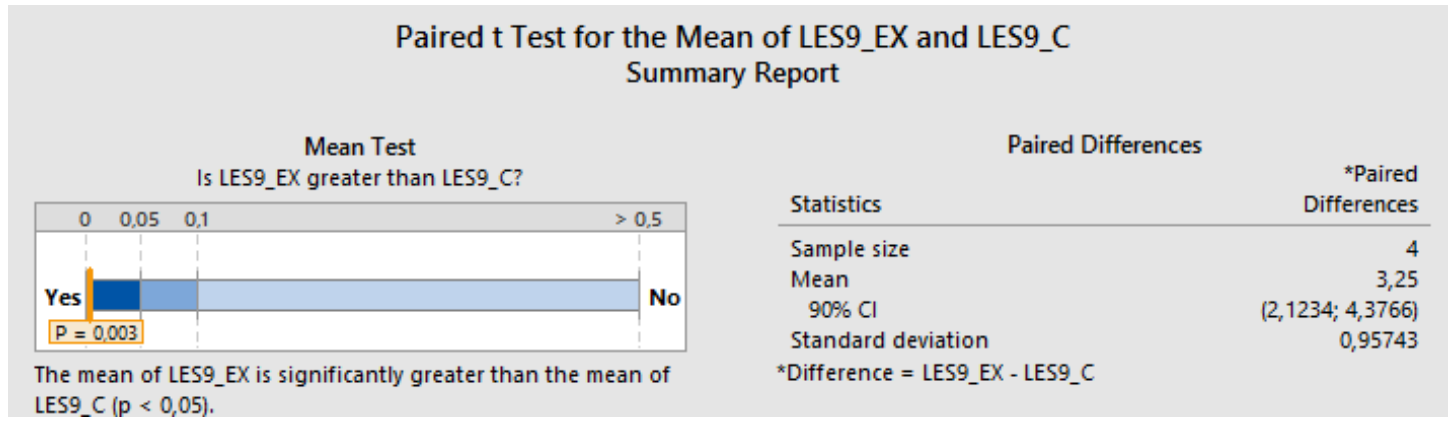

\begin{tabular}{lrr}
\multicolumn{2}{c}{ Individual Samples } \\
Statistics & LES9_EX & \multicolumn{1}{c}{ LES9_C } \\
\hline Mean & 7 & 3,75 \\
Standard deviation & 0 & 0,95743
\end{tabular}

In the post-test concerning the tenth lesson, the mean score for the experimental group is 12.5 while the mean score for the control group is 7.25 . The variation by subtracting the two mean scores is 5.25 and because the result is positive, it indicates that the experimental group performed significantly better than the control group. What is more, the p-value is 0.002 $(p<0.05)$ which suggests that there is a variation between the two mean scores, and this difference is also statistically significant. 


\section{Macrothink}

Journal of Studies in Education

ISSN 2162-6952

2017, Vol. 7, No. 3

Report 10: Paired T-test for the mean of the experimental and the control group concerning the tenth lesson (alphabet $\mathrm{Aa} / \mathrm{Mm}$ )

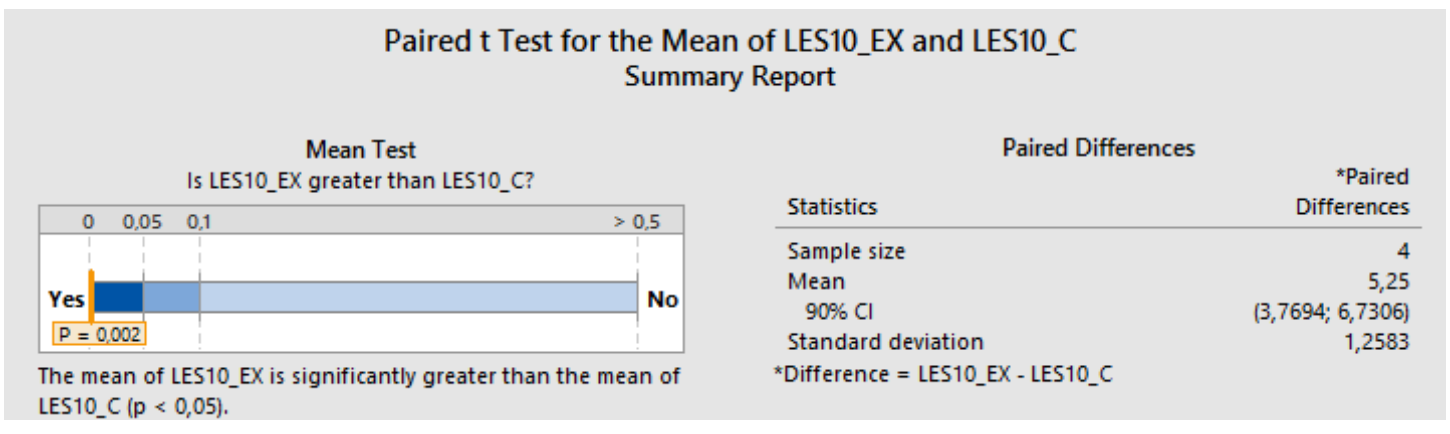

\begin{tabular}{lrr}
\multicolumn{2}{c}{ Individual Samples } \\
Statistics & LES10_EX & \multicolumn{1}{c}{ LES10_C } \\
\hline Mean & 12,5 & 7,25 \\
Standard deviation & 0,57735 & 0,95743
\end{tabular}

Last but not least, Report 11 indicates that the mean score for the experimental group is 12.5 while the mean score for the control group is 8.25 . The variation by subtracting the two mean scores is 4.25 and because the result is positive, it indicates that the experimental group performed significantly better than the control group. What is more, the p-value is 0.005 $(p<0.05)$ which suggests that there is a variation between the two mean scores, and this difference is also statistically significant.

Report 11: Paired T-test for the mean of the experimental and the control group concerning the eleventh lesson (alphabet $\mathrm{Nn} / \mathrm{Zz}$ )

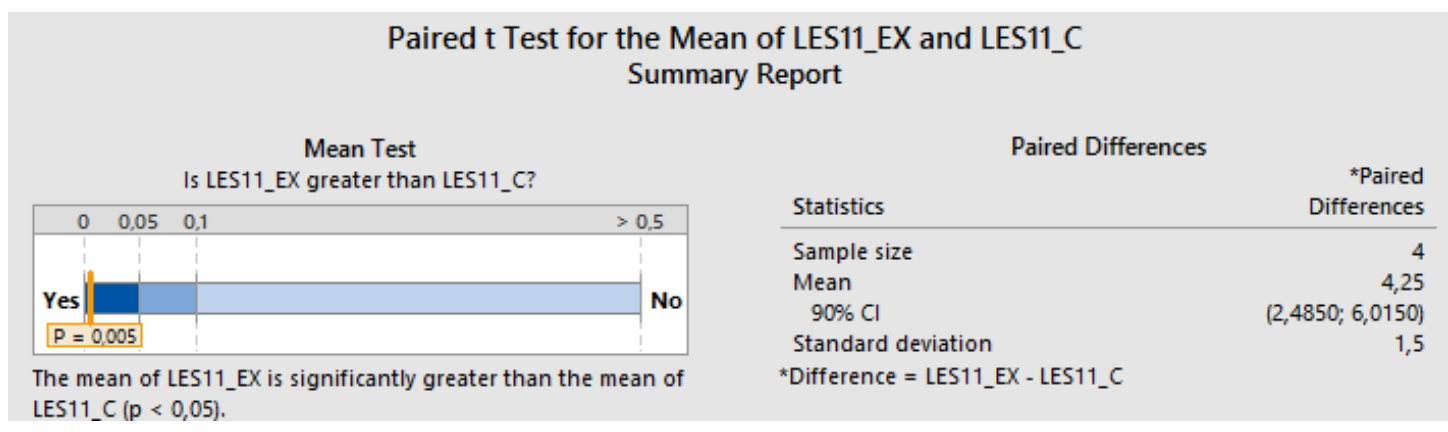

\begin{tabular}{lrr}
\multicolumn{3}{c}{ Individual Samples } \\
Statistics & LES11_EX & \multicolumn{1}{c|}{ LES11_C } \\
\hline Mean & 12,5 & 8,25 \\
Standard deviation & 0,57735 & 0,95743 \\
\end{tabular}

\subsection{Analysis of the final post test}

The results of the final post-test presented in the following report make it evident that the experimental group exhibited significant improvement in their performance after the end of 


\section{Macrothink}

Journal of Studies in Education

ISSN 2162-6952

2017, Vol. 7, No. 3

the lessons which could be attributed to the effect of the proposed intervention. More particularly, the mean score for the experimental group is 18.5 while the mean score for the control group is 11.75 . The variation by subtracting the two mean scores is 6.75 and because the result is positive, it indicates that the experimental group performed significantly better than the control group. What is more, the $p$-value is $0.001(\mathrm{p}<0.05)$ which suggests that there is a variation between the two mean scores, and this difference is also statistically significant.

\section{Report 12: Paired T-test for the mean of the experimental and the control group conducted after the end of the intervention}

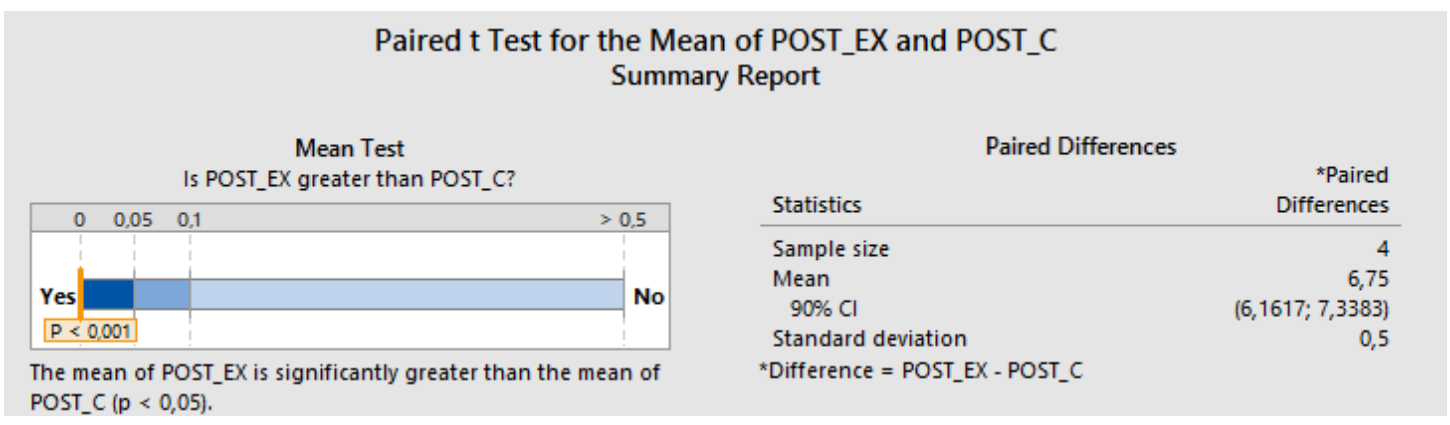

\begin{tabular}{lrr}
\multicolumn{3}{c}{ Individual Samples } \\
Statistics & POST_EX & POST_C \\
\hline Mean & 18,5 & 11,75 \\
Standard deviation & 0,57735 & 0,95743
\end{tabular}

What is more, a comparison between the pre- and post-test of the control and the experimental group has also been carried out separately. As far as the control group is concerned, the analysis illustrates that the mean score before the lessons was 3 while after the end of the lessons it was 11.75. This means that the students of the control group have improved their performance with a total mean score of 8.75 and a p-value of $0.001(p<0.05)$ (Report 13). However, the paired T-test conducted for the experimental group showed that the mean score before the intervention was 2.75 while after the end of it was 18.5 (Report, 14). The variation by subtracting the two mean scores is 15.75 , which indicates that the mean score of the experimental group was significantly higher than that of the control group. Moreover, the $\mathrm{p}$-value was $0.001(\mathrm{p}<0.05)$ which suggests that the difference between the two mean scores is also statistically significant. Therefore, it can be concluded that the experimental group has outperformed the control group, which may be attributed to the effect of the proposed intervention, as already mentioned above. 


\section{Macrothink}

Journal of Studies in Education

ISSN 2162-6952

2017, Vol. 7, No. 3

Report 13: Paired T-test conducted for the comparison of the pre- and post-test of the control group

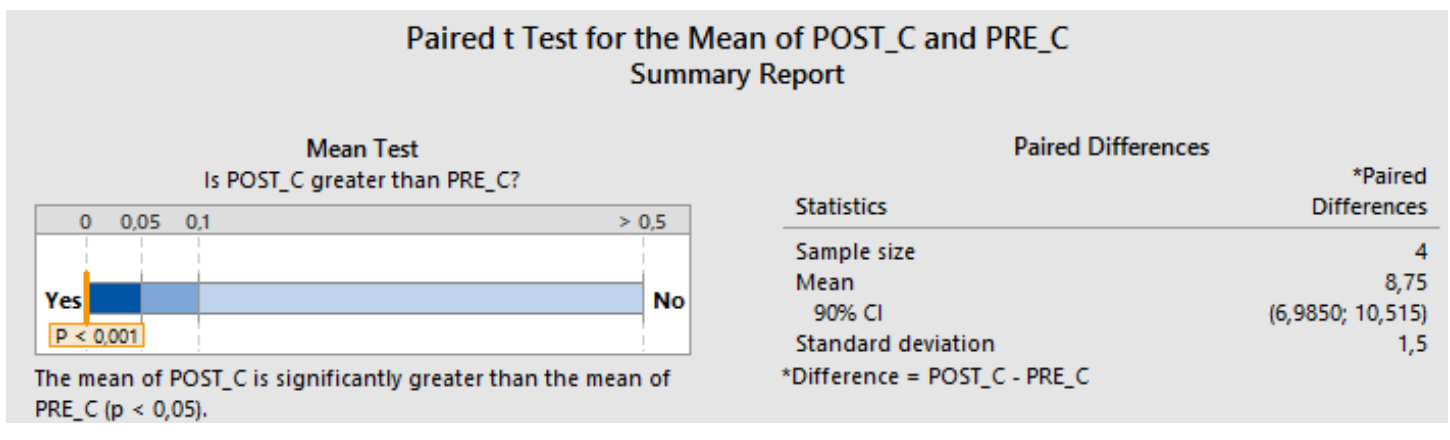

\begin{tabular}{lrr}
\multicolumn{3}{c}{ Individual Samples } \\
Statistics & POST_C & PRE_C \\
\hline Mean & 11,75 & 3 \\
Standard deviation & 0,95743 & 0,81650
\end{tabular}

Report 14: Paired T-test conducted for the comparison of the pre- and post-test of the experimental group

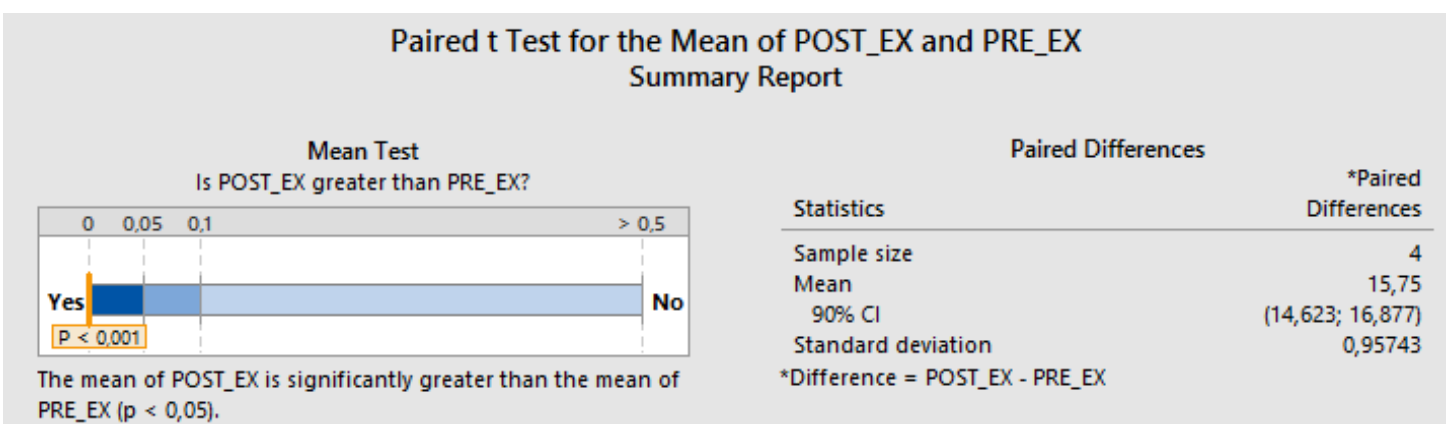

\begin{tabular}{lrr}
\multicolumn{3}{c}{ Individual Samples } \\
Statistics & POST_EX & PRE_EX \\
\hline Mean & 18,5 & 2,75 \\
Standard deviation & 0,57735 & 0,5
\end{tabular}

\section{Discussion}

This section summarizes the data collected from both the qualitative and quantitative tools in order to provide answers to the research questions which follow. Thus, in relation to the first question, "how can board games motivate six year old students to learn vocabulary", the outcomes that emerged from the analysis of the interviews conducted with the students of the experimental group indicated that the use of the proposed board games enhanced students' motivation, interest and learning effectiveness. Moreover, it was noticed that the students of the experimental group drew closer to each other and they built a better social relationship cooperating effectively as a team, although the element of competition was evident while playing. 
In response to the second research question, "in what way do board games have a positive effect on students' vocabulary knowledge" and the third research question, "can board games help young learners of the specific age to remember the target vocabulary better in comparison to the traditional book-based method", the results obtained from the post-tests demonstrated that the students of the experimental group performed better than the students of the control group. Moreover, the results which emerged from the comparison of the preand the post-test of both groups separately, showed that eventually the mean score achieved by the students of the experimental group was significantly higher, which indicates that they benefited from the particular intervention.

To sum up, the students felt that they gained knowledge by practising through board games and they hoped to continue learning English as a foreign language in a playful manner.

\section{Conclusion}

The purpose of this study was to determine whether board games could assist six year old students in learning basic vocabulary words related to topics which are appropriate for their age and language level. The participants displayed motivation towards the use of the adapted board games and felt that they contributed to their learning. However, there are a number of limitations to be considered.

The findings of this study are restricted because of the small number of participants. Because of the fact that only eight students from local regions took part in the research, it inevitably means that the findings of the study cannot be generalized and applied to all teaching contexts because the particular sample does not represent all students of the particular age group.

In addition, because of the fact that the students were very young and moreover it was the first time that the students had participated in an interview, they were not as communicative as it was expected, even though the semi-structured interview was designed in a way so as to yield detailed accounts from students.

All things considered, although only tentative conclusions could be drawn, even with such a small sample, the particular study added to the body of knowledge pertaining to the effectiveness of using games so as to achieve better results in vocabulary learning and thus language development. That being the case, it is suggested that future studies be conducted, which will include a more representative sample of participants, in order to provide an in-depth analysis on students' learning and motivation with the use of board games.

\section{References}

Aslanabadi, H., \& Rasouli, G. (2013). The effect of games on improvement of Iranian EFL vocabulary knowledge in kindergartens. International Review of Social Sciences and Humanities, 6(1), 186-195.

Billinghurst, M., \& Kato, H. (2002). How the virtual inspires the real. Communications of the ACM, 45(7), 64-70. 
Black, M. M. (2004). Measuring the impact of HIPPY on children: Pre/post testing. Retrieved from

http://www.hippyusa.org/memanage/pdf/MeasuringTheImpactOfHippyonChildrenPrePostTe sting.pdf

Bouniol, P. (2004). Learning theories. In P. Bouniol, \& K. Zouganeli (Eds), Teaching English to Young Learners (pp. 65-123). Patras: Hellenic Open University.

Bromley, K. (2007). Nine things every teacher should know about words and vocabulary instruction. Journal of Adolescent and Adult literacy, 50, 528-537. https://doi.org/10.1598/JAAL.50.7.2

Broughton, G., Brumfit, C., Flavell, R., Hill, P., \& Pincas, A. (2003). Teaching English as a foreign language. New York: Routledge.

Bruner, J. (1983). Child's talk: Learning to use the language. Oxford: Oxford University Press.

Burns, A. (2010). Doing action research in language teaching: A Guide for practitioners. New York: Routledge.

Cameron, L. (2001). Teaching English to young learners. Cambridge: Cambridge University Press.

Couzin, M. (2002). Benefits of board games. Retrieved from http://www.yourneighborhoodtoystore.org/play-together.asp?i=89

Creswell, J. W. (2014). Research design: Qualitative, quantitative and mixed methods approach. London: SAGE Publications Ltd.

Cunningham, P.M. (2009). What really matters in vocabulary: Research-based practices across the curriculum. Boston: Pearson Professional Development.

Curriculum Development Council (2002). English language education. Retrieved from http://www.edb.gov.hk/en/curriculum-development/kla/eng-edu/curriculum-documents.html

Dalton, E. (2006). Language Learning Games: Why, When, and How. Retrieved from https://www.google.gr/url?sa=t\&rct=j\&q=\&esrc=s\&source=web\&cd=1\&ved=0ahUKEwjN0 YaEibHUAhXkIMAKHZi4DscQFgglMAA\&url=http\%3A\%2F\%2Fgaeacoop.org\%2Fdalton \%2Fpublications\%2FLanguageGames.pdf\&usg=AFQjCNFm42W95On4W5AzpKynauBpjsg syA\&sig2=JQttwJ2gQU7Nx8Rq-Eo-MA\&cad=rja

Dewey, J. (1990). The school and society and the child and the curriculum. Chicago: The University of Chicago Press.

Dörnyei, Z. (2007). Research methods in applied linguistics: Quantitative, qualitative and mixed methodologies. Oxford: Oxford University Press.

Ersoz, A. (2000). Six games for the EFL/ESL classroom. The Internet TESL Journal. Retrieved from http://iteslj.org/Lessons/Ersoz-Games.html 
Fredericksen, E. (1999). Playing through: Increasing literacy through interaction. Journal of Adolescent and Adult Literacy, 43(2), 116-124.

Gardner, H. (1993). Multiple intelligences: The theory in practice. United States of America: Basic Books.

Gay, L. R., Mills, G. E., \& Airasian, P. (2003). Educational research: Competencies for analysis and applications. United States of America: Pearson Education, Inc.

Gerring, J. (2004). What is a case study and what is it good for? American Political Science Review, 98(2), 341-354. https://doi.org/10.1017/S0003055404001182

Gower, R., Philips, D., \& Walters, S. (2005). Teaching Practice: A handbook for teachers in training. Oxford: Macmillan Education.

Graves, M. F., August, D., \& Mancilla-Martinez, J. (2013). Teaching vocabulary to English language learners. Foreword by Catherine E. Snow. New York: Teachers

College Press.

Hadfield, J. (1999). Beginners’ communication games. United Kingdom: Longman.

Halliwell, S. (1992). Teaching English in the primary classroom. United Kingdom: Longman.

Hinebaugh, J. P. (2009). A board game education: Building skills for academic success. United States of America: Rowman \& Littlefield Education.

Hoffman, L., Templin, J., \& Rice, M. L. (2012). Linking outcomes from Peabody Picture Vocabulary Test forms using item response models. Journal of Speech, Language and Hearing Research, 55, 754-763. https://doi.org/10.1044/1092-4388(2011/10-0216)

Holden, W. R. (1999). Learning to learn: 15 vocabulary acquisition activities. Modern English Teacher, 8(2), 42-47. Retrieved from https://www.google.gr/url?sa=t\&rct=j\&q=\&esrc=s\&source=web\&cd=3\&cad=rja\&uact=8\&v ed=0ahUKEwj3kcHkj7HUAhVYOMAKHb3MCMQQFggyMAI\&url=http $\% 3 \mathrm{~A} \% 2 \mathrm{~F} \% 2 \mathrm{Ffile}$ s.eric.ed.gov\%2Ffulltext\%2FED450589.pdf\&usg=AFQjCNF4sXXoQH-umKQuAWe7IzYH b_MLtw\&sig2=igu5napVu670QBXTy2xaoA

Huang, A., \& Levinson, D. (2012). To game or not to game: Teaching transportation planning with board games. Transportation Research Record: Journal of the Transportation Research Board, 2307(15), 141-149. https://doi.org/10.3141/2307-15

Kapp, K. M., Blair, L. \& Mesch, R. (2014). The gamification of learning and instruction fieldbook: Ideas into practice. San Francisco: Wiley.

Kemmis, S., \& McTaggart, R. (1988). The action research planner. Geelong, Victoria: Deakin University Press. 
Kirriemuir, J., \& Mcfarlane, A. (2004). Literature review in games and learning, NESTA futurelab research report. Retrieved from https://telearn.archives-ouvertes.fr/hal-00190453/document

Kirikkaya, E. B., Iseri, S., \& Vurkaya, G. (2010). A board game about space and solar system for primary school students. Turkish Online Journal of Education Technology, 9(2), 1-13.

Krashen, D. S. (1987). British Council Conference. Milan.

Kuhne, G. W., \& Quigley, B. A. (1997). Understanding and using action research in practice settings. New Directions for Adult and Continuing Education, 73, 23-40. https://doi.org/10.1002/ace.7302

Lane, C. (2006). Multiple intelligences. The Distance Learning Technology Resource Guide. Retrieved from http://tis-london.org/uploads/documents/Multiple-intellengences.pdf

Langran, J., \& Purcell, S. (1994). Teaching languages to adults: Language games and activities. London: Centre for information on language teaching and research.

Laufer, B. (1997). The lexical plight in second language learning: Words you don't know, words you think you know and words you can't guess. In J. Coady \& T. Huckin (Eds), Second language vocabulary acquisition: A rationale for pedagogy. New York: Cambridge University Press, 20-34.

Lee, S. K. (1995). Creative games for the language class. Forum, 33(1). Retrieved from https://www.google.gr/url? sa $=$ t\&rct $=\mathrm{j} \& \mathrm{q}=\&$ esrc $=$ s\&source $=$ web $\& \mathrm{~cd}=1 \& \mathrm{cad}=\mathrm{rja} \& u a c t=8 \& \mathrm{v}$ ed=0ahUKEwj9orDdlLHUAhViAsAKHeCABZ4QFgghMAA\&url=http\%3A\%2F\%2Fdosfa n.lib.uic.edu $\% 2$ Fusia $\% 2$ FE-USIA $\% 2$ Fforum $\% 2$ Fvols $\% 2$ Fvol33\%2Fno1\%2FP35.htm\&usg= AFQjCNHKn2-GKgOBTcVCE6XHyPx-d7_K8A\&sig2=3uXX4pNqdWmG0pMqYOAXmw

Lewis, M. (1993). The lexical approach: The state of ELT and a way forward. Hove: Language Teaching Publications.

Lewis, G., \& Bedson, G. (1999). Games for children. Oxford: Oxford University Press.

Lightbown, P., \& Spada, N. (2000). How languages are learned. Oxford: Oxford University Press.

Mehregan, M. (2014). Game-based tasks for foreign language instruction: Perspectives on young learners' vocabulary acquisition. The IAFOR Journal of Language Learning, 1(1), 1-12. https://doi.org/10.22492/ij11.1.1.03

Mills, A. J., Eurepos, G., \& Wiebe, E. (Eds). (2010). Encyclopedia of case study research. USA: SAGE Publications Ltd. https://doi.org/10.4135/9781412957397

Minitab17 (2017). Retrieved from https://www.minitab.com/en-us/products/minitab/

Mubaslat, M. M. (2012). The effect of using educational games on students' achievement in English language for the Primary stage. Retrieved from https://www.google.gr/url?sa=t\&rct=j\&q=\&esrc=s\&source=web\&cd=2\&ved=0ahUKEwjcjv 
zbkaPSAhUDL8AKHVuzCWUQFggfMAE\&url=http\%3A\%2F\%2Ffiles.eric.ed.gov\%2Ffullt ext\%2FED529467.pdf\&usg=AFQjCNE9UK0j01Znov521zn0hzbD6Vcb0A\&sig2=dhUGpNR QRA7zH-oBbHKKbA\&bvm=bv.147448319,d.bGg\&cad=rja,

Oxford, R., \& Crookall, D. (1990). Vocabulary learning: A critical analysis of techniques. TESL Canada Journal, 7(2), 9-30. https://doi.org/10.18806/tesl.v7i2.566

Pàlànova, K. (2010). Use of games in English language. Published Bachelor Thesis, Masaryk University.

Papastergiou, M. (2009). Digital game-based learning in high school computer science education: Impact on educational effectiveness and student motivation. Computers and Education, 52(1), 1-12. https://doi.org/10.1016/j.compedu.2008.06.004

Papert, S., \& Harel, I. (1991). Constructionism. Norwood: Ablex Publishing Corporation.

Phakiti, A. (2014). Experimental research methods in language learning. London, UK and New York, NY: Bloomsbury Publishing Plc.

Philip, J., Oliver, R., \& Mackey, A. (2008). Second language acquisition and the younger learner: Child's play?. Philadelphia, PA: John Benjamins Publishing Company. https://doi.org/10.1075/11lt.23

Piaget, J. (1967). Six psychological studies. New York: Random House.

Razak, N.Z.B.A., \& Eswaran, J.A.P. (2013). Investigating the ESL teachers' and students' attitude towards the use of computer in English language classroom.

Richards, J. C., Platte, J., \& Platte, H. (1992). Dictionary of language teaching and applied linguistics. London: Longman.

Richards, K. (2003). Qualitative inquiry in TESOL. New York: Palgrave Macmillan. https://doi.org/10.1057/9780230505056

Riley, J. (Ed). (2003). Learning in the early years. London: SAGE Publications Ltd.

Rivers, W. M. (1968). Teaching foreign language skills. Chicago: University of Chicago Press.

Rubin, J., \& Thompson, I. (1994). How to be a more successful language learner. Boston: Heinle and Heinle Publishers.

Schmitt, N. (2010). Researching vocabulary: A vocabulary research manual. England: Palgrave Macmillan. https://doi.org/10.1057/9780230293977

Scott, W. A., \& Ytreberg, L.H. (1991). Teaching English to children. London, UK and New York, NY: Longman.

Shin, K. J., \& Crandall, J. (2014). Teaching young learners English: From theory to practice. Boston: Heinle Cengage Learning 


\section{IIMacrothink}

Journal of Studies in Education

ISSN 2162-6952

2017, Vol. 7, No. 3

Siggelkow, N. (2007). Persuasion with case studies. Academy of Management Journal, 59(1), 20-24. https://doi.org/10.5465/AMJ.2007.24160882

Slattery, M., \& Willis, J. (2001). English for primary teachers. Oxford: Oxford University Press.

Stanovich, K. (2000). Progress in understanding reading: Scientific foundations and new frontiers. New York: Guilford Press.

Thornbury, S. (2002). How to teach vocabulary. England: Pearson Education Limited.

Treher, E. N. (2011). Learning with board games: Tools for learning and retention. Retrieved from http://www.thelearningkey.com/pdf/Board_Games_TLKWhitePaper_May16_2011.pdf

Uberman, A. (1998). The use of games for vocabulary presentation and revision. Forum, 36(1), 20-27.

Vernon, S. A. (2009). ESL Games: 176 English language games for children. United States of America: Create Space Independent Publishing Platform.

Vygotsky, L. (1962). Thought and language. New York: Wiley. https://doi.org/10.1037/11193-000

Vygotsky, L. (1978). Mind in society. Cambridge, MA: Harvard University Press.

Wallace, M. (1991). Training foreign language teachers: A reflective approach. Cambridge: Cambridge University Press.

Wilkins, D. (1972). Linguistics in language teaching. London: Arnold.

de Winter, J. C. F. (2013). Using the student's t-test with extremely small sample sizes. Practical Assessment, Research \& Evaluation, 18(10), 1-12.

Wu, C. J., Chen, G. D., \& Huang, C.W. (2014). Using digital board games for genuine communication in EFL classrooms. Education Technology Research and Development, 62, 209-226. https://doi.org/10.1007/s11423-013-9329-y 